\title{
Das viagens e exílios de Alejo Carpentier
}

\author{
Amanda Brandão Araújo Moreno ${ }^{1}$
}

Resumen: Alejo Carpentier, a ejemplo de otros grandes nombres de la literatura universal, fue un gran viajante. Sus deslocamentos tuvieron múltiples motivaciones y muchas veces fueron motivados por el exilio, por la imposibilidad de decir y de existir en un determinado lugar así como se entendía y quería ser. En la dimensión de la experiencia, sin embargo, no siempre los relatos del autor sobre los tiempos de exilio y expatriación denotan, necesariamente, una fractura identitaria, una forma de no-ser. Percibimos, por lo contrario, relatos biográficos de exilios marcados por descubrimientos y aprendizajes sobre su tierra natal, menos que por añoranzas y sufrimientos. En ese sentido, este trabajo busca analizar y dar énfasis a lo que es dicho textualmente, en detrimento de lo no dicho, buscando observar cómo ocurre la representación de la experiencia del exilio vivido por Alejo Carpentier, sobre todo en el conjunto de su biografía. Balizan las discusiones propuestas, entre otros, los trabajos de Said (2003), Bolaño (2001), Ianni (2003), Montañés (2006) y Rolemberg (1999). Los cotejos realizados dan lugar a la idea de que, para el referido autor, al revés de lo propuesto por importantes nombres que abordaron el tema, el exilio no fue, en primera instancia, un trauma, pero un agente propiciador de la reflexión y la configuración de una identidad y proyecto literario relacionado a ella. Palabras clave: exilio; viaje; Alejo Carpentier.

Resumo: Alejo Carpentier, a exemplo de outros grandes nomes da literatura universal, foi um grande viajante. Seus deslocamentos tiveram motivações múltiplas e não raro se deveram ao exílio, à impossibilidade do dizer e do existir num determinado lugar tal como se entendia e queria ser. No entanto, na dimensão da experiência, nem sempre os relatos do autor sobre os tempos de exílio e expatriação denotam necessariamente uma fratura identitária, uma forma de não ser. Percebemos, ao contrário, relatos biográficos de exílios marcados por descobrimentos e aprendizados sobre sua terra natal, menos que por saudades e sofrimentos. Nesse sentido, este trabalho busca analisar e enfatizar o que é dito textualmente, em detrimento do não dito, buscando observar como se dá a representação da experiência do exílio vivido por Alejo Carpentier, sobretudo no conjunto de sua biografia. Balizam as discussões propostas, entre outros, os trabalhos de Said (2003), Bolaño (2001), Ianni (2003), Montañés (2006) e Rolemberg (1999). Os cotejos realizados apontam para a ideia de que, para o autor em questão, ao contrário do que expressa uma forte corrente sobre o tema, o exílio não foi

1 Doutora em Teoria da Literatura pela Universidade Federal de Pernambuco (UFPE). Professora de Língua e Literatura de Língua Espanhola do Departamento de Letras da Universidade Federal Rural de Pernambuco (UFRPE), onde lidera o Grupo de Pesquisa "Narrativas hispano-americanas do século XX" e coordena o Projeto de Pesquisa "O realismo maravilhoso em narrativas hispano-americanas do século XX". 
tanto um trauma, mas um agente propiciador da reflexão e configuração de uma identidade e projeto literário ancorado nesta.

Palavras-chave: exílio; viagens; Alejo Carpentier.

\title{
Introdução
}

\author{
"La figura de la extradición es la patria del escritor (...) obligado \\ siempre a recordar una tradición perdida, forzado a cruzar la frontera" \\ Ricardo Piglia
}

"O homem está na cidade/ como uma coisa está na outra/ e a cidade está no homem/ que está em outra cidade"

Ferreira Gullar

Na dimensão da experiência, o exílio é um estado - ou condição - multiforme. A perspectiva imposta para sua vivência pode assumir formas bastante antagônicas quando se experimenta o desterro forçado, o banimento, o refúgio ou a expatriação voluntária. Cada uma dessas "categorias" poderia ser ainda subdividida em outras segundo os mais variados critérios que se quisesse adotar para traçar um panorama de seus matizes. Edward Said (2003), a partir de seu lugar de fala, expõe uma experiência que entende o exílio como uma mutilação, uma tristeza essencial, "uma fratura incurável entre um ser humano e um lugar natal, entre o seu eu e seu verdadeiro lar" (2003, p. 46), um "estado de ser descontínuo" (p. 50), uma "perda desorientadora" (p. 54) e condena, portanto, a visão simplista daqueles que reduzem o exílio a uma experiência benéfica que gesta arte e expande limites. Maria Florencia Magriñá (2013) observa o exílio como a "existência a partir de ausências" (2013, p. 05) e o exilado como "alguém que vive entre versatilidade e indeterminação (...), em meio a uma ambiguidade trágica entre a sua situação e a esperança de retorno" (2013, p. 05). A figura do exilado seria, portanto, cindida, fragmentada.

$\mathrm{Na}$ contramão do que argumenta o intelectual palestino, Roberto Bolaño observa a experiência do exílio não como a marca fatal de uma mutilação, mas como o destino operado pelo azar que propicia o retorno da dignidade para aqueles que, em sua pátria, haviam-na perdido. Em texto intitulado El exilio y la literatura, o escritor chileno observa que

por el aire de Europa suena una cantinela del dolor de los exilados, una música hecha de quejas y lamentaciones y una nostalgia difícilmente inteligible. ¿Se puede tener nostalgia por la tierra en donde uno estuvo a punto de morir? ¿Se puede tener nostalgia de la pobreza, de la intolerancia, de la prepotencia, de la injusticia? (BOLAÑO, 2001, p. 43).

No terreno da expressão, são igualmente irregulares as formas de plasmar o exílio, tanto no nível da narrativa em si mesma, quanto na relação de um autor com o tema. Bolaño vaticina que "para el escritor de verdad su única pátria es su biblioteca, una biblioteca que puede estar en estanterías o dentro de su memoria" (2001, p. 43). Nesse sentido, o exílio poderia ter lugar na terra natal, se aí se operassem privações que tolhessem certas formas do existir. Amanda Pérez Montañes entende que "o exílio não é só um estado físico, espacial e temporal, também é um estado mental” (2006, p. 176) e ao poeta que, uma vez tendo sofrido uma usurpação, uma perda primordial, restaria apenas como forma 
de resistência e sobrevivência a "apropriação simbólica do espaço imaginário". Sendo assim, "a verdadeira pátria do escritor sem pátria, suas raízes, estão no livro que o poeta carrega dentro de si” (2006, p. 177).

Neste trabalho, não pretendemos em nenhuma medida negar a validade e dimensão de realidade e profunda tristeza das experiências de exílio retomadas por Edward Said em seu emblemático livro. Experiências fatais, fruto da intolerância e do ódio que engendram na geografia e nos espíritos fraturas incuráveis. O que gostaríamos de aventar aqui é a existência de outras experiências de exílio, menos indignas e lacerantes e que, ao invés de negar a identidade, opera em sentido senão oposto, paralelo, proporcionando-a. Uma experiência, talvez, privilegiada do exílio e que não é de todo ignorada por Said, que admite essa possibilidade ao comentar que "ver "o mundo inteiro como uma terra estrangeira’ possibilita a originalidade da visão. A maioria das pessoas tem consciência de uma cultura, um cenário, um país; os exilados têm pelo menos dois desses aspectos, e essa pluralidade de visão dá origem a uma consciência de dimensões simultâneas" (2003, p. 59).

Denise Rollemberg (1999) argumenta que estudar o exílio é, antes de tudo, estudar o exilado. Nesse contexto, o objetivo deste trabalho é elaborar um panorama de como exílios, num sentido mais estrito, e viagens, num mais amplo, propiciaram experiências que foram fundamentais para a construção do projeto literário de Alejo Carpentier, mas que ultrapassaram as fronteiras da literatura (se é que existe tal coisa) e engendraram o delineamento da ideia de identidade cubana e latino-americana do autor. Nossa discussão passa pela percepção de que os relatos de exílio elaborados por Carpentier não demonstram uma fratura identitária, mas a possibilidade de criar um ambiente mental propício à reflexão sobre a identidade a partir da ausência e da expatriação. Considerando o exposto, vale ainda apontar que nossas análises estarão pautadas num viés muito mais próximo ao biográfico que do narrativo ficcional, muito embora este seja considerado e comentado ao longo do texto, sobretudo naquilo que as experiências dos deslocamentos condicionaram na escrita de romances. Buscamos, por fim, identificar e analisar como se operou a "consciência de dimensões simultâneas" na vida e projeto literário de Alejo Carpentier.

\section{Carpentier: uma metáfora da viagem ${ }^{2}$}

O caminhante devaneia sobre a estrada e a travessia, o que vê e o que não vê, o que aprende e o que imagina que sabe, a aparência e a essência, o ser e o devir. Pode descobrir que na parte ressoa o todo, que o singular carrega o halo do universal. Esse o percurso em que se perde e encontra, forma e transforma. E pode até mesmo reencontrar-se, transfigurado em outro de si mesmo. [...] Trata-se de aprender a ver o que é nosso como se fôssemos estrangeiros, e como se fosse nosso o que é estrangeiro.

(Octavio Ianni, em A metáfora da viagem)

Quanto de história cabe em 75 anos? Certamente para responder a uma questão como essa - no mínimo mal formulada e pouco usual -, seria necessário impor outras indagações, como "na vida de quem?", "falamos de um indivíduo ou de uma nação?", "impor-

2 O texto que ora se apresenta é uma versão parcialmente reformulada do Capítulo 2 da tese de doutorado intitulada Cartografia ensaistica de Alejo Carpentier, defendida em 2018 no âmbito do Programa de Pós-Graduação em Letras/Teoria da Literatura da Universidade Federal de Pernambuco. 
tam apenas os fatos mais significativos ou o passo a passo de tudo?", entre tantas outras possíveis que poderiam ser formuladas para vencer a dubiedade de uma pergunta tão truncada como a expressa acima.

Alejo Carpentier viveu por 75 anos no reino deste mundo, mas nesse lapso temporal conseguiu retomar tantos séculos de história e memória que seria uma árdua tarefa tentar mensurar os dados por ele levantados. Nos 75 anos em que viveu Carpentier parecem caber séculos de literatura, história, política e música. Ao tratarmos de sua biografia, necessariamente, recorreremos, em maior ou menor medida, à história de Cuba, de toda a América Latina, mas também da Europa e a traços de histórias de África, reinterpretados pela região caribenha.

Evidentemente seria uma empreitada e tanto conjugar essas histórias, tão amplas como o próprio Tempo. Carpentier, no entanto, sugeriu chaves através das quais seria possível arriscar um recorte viável entre a história e a memória que são por ele mesmo retomadas. A primeira chave de entrada é a viagem. Poderemos constatar, ao longo deste trabalho, a importância de viagens para a produção carpentieriana, sejam elas as realizadas pelo próprio autor, sejam elas pretéritas, misteriosas, conhecidas através de relatos, não raro fragmentados, reincidentemente retomados pela História.

Octavio Ianni (2003) diz que a história de todos os povos está "atravessada" pela viagem, seja como realidade, seja como metáfora. Segundo ele, todas as formas de sociedade "trabalham e retrabalham" a viagem como um modo de descobrir o outro ou a si mesmos, ultrapassando, dissolvendo e recriando fronteiras. Esse processo tanto singulariza como universaliza a cultura e a sociedade.

A história universal, e inevitavelmente sua literatura, registra um número expressivo de viajantes emblemáticos: Ulisses, Alexandre o Grande, Marco Polo, os cruzados, os navegantes, como Colombo, Vespúcio, Fernão de Magalhães, Camões, Próspero, Robinson Crusoé, Napoleão Bonaparte, Humboldt, Darwin, Goethe. Alguns destes, em especial, marcam a produção carpentieriana. A viagem é presença constante em suas obras, mesmo naquelas que não expressam uma transposição espacial concreta, mas uma dimensão psicológica. Ianni argumenta que "mesmo os que permanecem, que jamais saem do seu lugar, viajam imaginariamente ouvindo histórias, lendo narrativas, vendo coisas, gentes e signos do outro mundo" (2003, p. 14). Ti Noel, personagem de El reino de este mundo (1949), é frequentemente fascinado pelas estórias de Mackandal: embora não tenha sido um grande viajante, a viagem é substância de sua realidade. "A viagem pode alterar o significado do tempo e do espaço, da história e da memória, do ser e do devir. Leva consigo implicações inesperadas e surpreendentes" (Ianni, 2003, p. 22). Seja como metáfora, seja como realidade, a viagem é mote fundamental da escrita carpentieriana e inevitavelmente "encurrala" a discussão sobre identidade e alteridade, o "eu" e o "outro" se embaralham e definem-se durante as diferentes etapas de deambulação. Em Los passos perdidos (1953) identificamos esse processo através das descobertas do viajante que, "ao longo da travessia, não somente encontra-se, mas reencontra-se, já que se descobre mesmo e diferente, idêntico e transfigurado. Pode até revelar-se irreconhecível para si próprio" (Ianni, 2003, p. 26).

Como realidade ou como metáfora, espontânea ou como exílio, a viagem define o destino das narrativas carpentierianas e das ideias que povoaram sua ensaística e é a partir dela que seus centros organizadores se desenvolvem, em maior ou menor medida. No entanto, não é só no âmbito da escrita que a viagem se instaura como decisiva em relação ao autor cubano. Sua biografia parece, ela também, representar um cronotopo da viagem. 
É pelo valor incontestável de como experiências de exílios e viagens marcaram a produção do autor que expomos um percurso mapeando os pontos decisivos para a construção de sua literatura e ensaística, a partir e de acordo com as viagens empreendidas por Carpentier e diretamente vinculadas a ele, as quais apontam, na dimensão da experiência, os percursos vividos pelo autor e sua necessária e indesvinculável relação com o Carpentier intelectual, com o Carpentier humanista.

\section{Estrangeiro na terra natal. Os primeiros passos (1904-1928)}

Apesar de grande parte da bibliografia a respeito de Carpentier não discutir o mérito da questão e considera-lo cubano, sem maiores adjetivações, citando seu local de nascimento como tendo sido Havana, é apontado por alguns de seus maiores especialistas, como Roberto González Echevarría (1990; 2014), Alexis Márquez Rodríguez (2008), e a própria Fundación Alejo Carpentier, que o autor nasceu em Lausanne, Suíça, em 26 de dezembro de 1904, sob o nome de Alexis Carpentier. Essa contradição entre as fontes se deve, muito provavelmente, a que Carpentier escondeu seu local de nascimento até sua morte, em 1980. Apenas depois de morto é que foi revelado que o escritor era, na verdade, suíço, e não cubano, como afirmou ser durante toda sua vida (ver Echevarría, 2014). Seu pai, George Julián Carpentier, um arquiteto e músico francês da cidade de Marsella, e sua mãe, Ekaterina Vladimirovna Blagoobrázova, russa, professora de música e idiomas, conhecida posteriormente como Lina Valmont, mudaram-se para Havana apenas em algum momento entre 1908 e 1909. Feita esta ressalva, por concordar com os estudos já publicados e por entender que o próprio Carpentier se considerava cubano de nascimento, e por ter sido majoritariamente cubana sua experiência na infância e a Cuba se vincular sua produção intelectual, é como cubano que o trataremos.

Assim sendo, nos primeiros anos do século XX nasce em Havana Alejo Carpentier y Valmont. Segundo um relato do autor, o que motivou a vinda de seus pais para a América foi a busca por um "novo clima”, na forma de expatriação voluntária.

Mi padre era dreyfusiano en el seno de una familia anti-dreyfusiana; había abandonado Europa para buscar verdaderamente un nuevo clima. De ahí mi nacimiento en Cuba. Por lo demás, este trasplante no dejaba de tener relación con mis orígenes familiares, ya que desciendo de marineros bretones, aventureros del mar desde el siglo XVIII. Estoy incluso orgulloso de ser bisnieto del primer explorador de la Guayana. (CARPENTIER, 1985, p. 152)

Nessa época, a condição de vida da família Carpentier em Cuba era cômoda. O autor diria, em entrevista a Ramón Chao $^{3}$ (1998, p. 313) na década de 1970, que seu pai participara ativamente da construção arquitetônica da República Cubana e que a ele se devia o planejamento de várias construções importantes da época, como bancos, residências proeminentes, o Country Club e a central elétrica de Tallapiedra. Na mesma entrevista,

3 A obra de Ramón Chao, citada neste trabalho como se tratando de "entrevistas", é, na verdade, uma elaboração de Chao, sem a resposta direta de Carpentier. Foram recolhidos textos de conferências, ensaios, declarações e artigos do autor os quais foram compilados em forma de entrevista, com autorização de Carpentier. A constante menção às "entrevistas" dadas ao jornalista que serão feitas neste trabalho se refere ao caráter do gênero do texto publicado e não ao seu processo de criação. 
Carpentier afirma que seus pais chegaram em Havana no ano de 1902 e que seu nascimento se dera dois anos mais tarde, a 26 de dezembro, na rua Maloja (apud CHAO, 1998, p. 313).

A infância de Alejo foi marcada por uma educação formal europeia mesclada à convivência cotidiana com os valores locais, afro cubanos. Seu perfil biográfico está insistente e intensamente marcado pela música. Seu pai era violoncelista, discípulo de Pau Casals; sua mãe, pianista, assim como sua avó, que foi aluna de César Franck. Desde os primeiros anos, Alejo estudou piano, harmonia, instrumentação e contraponto. Por volta dos dez anos de idade já executava ao piano grandes compositores.

Eram esses os tempos do nascimento da República de Cuba, recentemente emancipada do poder espanhol, época em que conviviam a prosperidade de um pequeno grupo e o desenvolvimento do caos econômico, político, social e cultural que tanto hão de marcar a vida do autor, já que as intensas atividades comerciais que a ilha realizava na época eram com os Estados Unidos, que tinham adquirido o direito de intervir política e economicamente no país, o que fez com que não houvesse a almejada soberania advinda da independência. Alejo foi uma criança de saúde precária, asmática, o que fez com que frequentemente se visse forçado a isolar-se em casa, fato que o aproximou ainda mais da literatura e da música. Seu pai era também grande conhecedor das literaturas francesa e espanhola. Em várias entrevistas, Carpentier comentava ser um leitor compulsivo, do qual não escapavam sequer rótulos e panfletos. Também lia partituras como se livros fossem, executando-as mentalmente.

Apesar da infância em Cuba, sua língua materna foi o francês. Aprendeu o espanhol durante a infância através de seus amigos de rua e dos funcionários de sua casa, com quem constantemente se reunia para ouvir histórias populares cubanas. Quando pensamos nas diferentes experiências de exílio, o desconhecimento do idioma é frequentemente apontado como dificuldade impossibilitadora do dizer e do existir socialmente. Essa não foi, no entanto, a experiência de Carpentier, que exilou-se sobretudo na Espanha, França e Venezuela (sendo esta última uma experiência voluntária), todos lugares cujos idiomas dominava muito bem. Por isso e por outros fatores, o autor sempre foi duramente criticado por um suposto afrancesamento de seus escritos. Em entrevista a Ramón Chao, quando inquirido sobre seu bilinguismo e sobre qual considerava ser sua primeira língua, responde:

El primero idioma que oí fue el español, por boca de la nodriza que me crió. Nací en una cuidad donde se hablaba español, y aprendí a leer y a escribir en colegios en los que se enseñaba en esa lengua. Pero también es cierto que mis padres me hablaban en francés en casa, por lo cual hablo ambos idiomas y puedo escribirlos. Algunas veces he escrito en francés, aunque debo confesar que me corregía Robert Desnos. [...] Además, el español es un idioma espléndido, de una flexibilidad, de una riqueza, de unos recursos literarios incomparables, y sobre todo ofrece facilidades extraordinarias al prosista y al poeta en cuanto a la posibilidad de jugar con la frase, con los verbos, de verbalizar sustantivos, en fin, de hacer estallar el idioma cuando hace falta e incluso inventar una palabra, transformar un sustantivo en verbo de tal manera que todo el mundo entiende y nadie califica una frase de oscura porque en ella se halle un verbo insólito inventado por el escritor. Con el castellano puede hacerse todo. No así con el francés. [...] Así pues, si escribí mi obra literaria en español, no es solamente porque considere que el francés es una lengua muy tiesa, sino porque el español es una de las lenguas más ricas del mundo. [...] El español es mucho más apropiado para relatar lo que me interesa: el mundo del Caribe, el puerto de Santiago, la cuidad vertical de Valparaíso, etcétera. (1998, p. 25-27) 
As críticas a sua suposta ambiguidade o perseguiriam durante toda a vida, sustentadas inclusive por vozes de muito prestígio, como a de Marinello ou Neruda. Ainda assim, vê-se em toda sua produção um esforço para naturalizar americanismos e o espanhol da América como um todo, em contraponto ao purismo hispânico.

O espanhol é a língua mais presente na educação formal de Carpentier. A posição de sua família permitiu que realizasse seus estudos em escolas particulares em Havana, primeiro no Colégio Mimó e depois no Candler College. Em 1913, então por volta dos nove anos, viajou à Europa, em companhia de seus pais, que iriam resolver questões de herança. Por esse motivo permaneceu alguns meses na Russia e um período em Paris, onde frequentou o Liceu Jeanson de Sailly. Quando completa onze anos, seu pai o envia de volta a Cuba para administrar uma propriedade familiar no campo, próxima a Havana. Essa experiência o coloca em contato mais intenso com a tradição antilhana, a qual irá se expressar particularmente na obra El reino de este mundo. Ao mesmo tempo em que estabelece contato com essa tradição, lê os clássicos franceses, em especial as obras de Balzac, Zola e Flaubert.

Quando completa treze anos, inicia os estudos no Instituto de Segunda Enseñanza, que correm paralelamente a seu bacharelado em música. Remontam a 1917 seus primeiros textos, constituídos sobretudo por prosas inspiradas pelos ciclones no Caribe. Aos quinze anos escreve um breve romance imitando Flaubert e Eça de Queiroz. Aos vinte anos volta ao campo, junto com sua família, a uma propriedade em Loma de la Tierra. Relata, anos depois, que esse período será decisivo para sua narrativa. É nesse momento que se prepara para cursar Arquitetura na Universidad de la Habana, na qual é aceito em 1921. No entanto, não levará muito adiante seus estudos, pois seu pai abandona a família e Carpentier se vê forçado a começar a trabalhar.

É no jornalismo que encontra espaço para, através da escrita, expor suas ideias e sustentar a casa. Em 1922 publica seus primeiros artigos na imprensa cubana. Escreve sobretudo a respeito das manifestações artísticas então aclamadas ou insurgentes no cenário nacional e internacional. Apenas um ano depois, em 1923, assume o cargo de editor da revista semanal Carteles, com a qual colabora até 1949. Contribui também com a revista Social e Diario de la Marina, ambos considerados de linha conservadora.

Ainda nos primeiros anos da década de 1920, começa a engajar-se mais diretamente com publicações sociais e políticas e se envolve com os movimentos de vanguarda. Esses anos são marcados pelas relações amistosas que trava com diversos intelectuais na capital cubana, como Juan Marinello, e outros de toda a América. Nos entornos de 1923, integra o Grupo Minorista, associação que terá importantes repercussões mais adiante. De teor anti-imperialista, o grupo tinha como conteúdos programáticos a defesa dos valores nacionais da cultura, acentuada preocupação com a classe operária e camponesa, aversão a ditaduras e estava composto por diversos artistas e intelectuais cubanos e do continente. Entre seus objetivos estava a luta contra o atraso cultural, que se manifestava a partir da valorização das vanguardas em Cuba e sua vinculação com outros grupos no continente e na Europa, sobretudo Espanha. Um dos feitos de maior notoriedade do Grupo foi a valorização de José Martí, até então pouco lido e apreciado no cenário pós-emancipação.

Os anos de 1920 são, em Cuba, tempos de intensa instabilidade política, representada pela constante intervenção estadunidense e pela ditadura de Gerardo Machado. O cenário político e o literário caminhavam quase sempre em vias opostas. Os confrontos de ideais não raro geravam problemas de diferentes envergaduras para os intelectuais. A associação 
de Alejo ao Grupo Minorista fez com que sofresse perseguições políticas, ainda quando não tinha sido responsável diretamente por alguma atividade do Grupo, como foi o caso, por exemplo, do que ficou conhecido como "Protesta de los Trece", liderada por componentes minoristas que foram perseguidos pelo então presidente cubano Alfredo Zayas. Em 1926, durante uma curta viagem ao México, Alejo conhece e estabelece contato com Diego Rivera e José Clemente Orozco, personalidades que também serão importantes para sua produção.

Os ideais do Grupo Minorista se projetam em grande parte dos escritos carpentierianos da época, em especial naqueles destinados à publicação na Revista de Avance, da qual ele era um dos cinco editores. Dita revista se somava à corrente de periódicos do continente que tinha como objetivo criar um ambiente favorável à escritura experimental e permitir que escritores locais lessem literatura estrangeira e se atualizassem sobre as produções artísticas da época. Echevarría e Pupo-Walker (2006) incluem o periódico na mesma lista que a argentina Martín Fierro, a mexicana Contemporáneos e a peruana Amauta. As quatro, juntas, cumpriam a função de "convertir el texto en un suceso público como forma de establecer un espacio para que el debate crítico retase a la sensibilidade dominante y subrayase su propia actividad privilegiada" (Echevarría \& Pupo-Walker, 2006, p. 141).

A Revista de Avance é considerada um episódio muito importante da história literária de Cuba, tendo sido publicados cinquenta números durante seus quatro anos de existência (1927-1930). Apesar da heterogeneidade pela qual era composta, era consenso que a revista propugnasse uma renovação integral da vida cubana. De acordo com Carlos Ripoll, "ella no recoge todos los matices de tan rico momento histórico [...] pero sí sintetiza su ideario esencial y el énfasis renovador de la época. Llegó a ser como una resultante de las fuerzas que quisieron conmover el acontecimiento artístico para trascender en la vida nacional" (1964, p. 262).

Por ter firmado a declaração do Grupo Minorista, na qual se declarava contrariedade ao governo, Carpentier é preso em julho 1927, considerado comunista. Em agosto o juiz decreta sua liberdade provisória com base em fiança e exílio ou impossibilidade de deixar a capital cubana, o que Carpentier nega, inicialmente, e permanece preso. É nesse período que escreve o esboço de sua primeira novela, Écue-Yamba-Ó. Algumas semanas depois sai da prisão, através do pagamento de fiança.

Em liberdade condicional, abandona a redação da Revista de Avance, ainda que continue enviando contribuições para publicação. Sua saída, no entanto, não enfraquece o teor da revista, que tem dimensões continentais e participa, inclusive, de debates internacionais. O compromisso da revista com a luta contra o imperialismo fazia com que houvesse uma grande participação de intelectuais de toda a América Latina. O ano de 1927 marca também a discussão em torno de uma polêmica gerada pelo autor Guillermo de Torre, que escreveu um artigo intitulado Madrid, meridiano intelectual de Hispanoamérica. Esse texto foi recebido como grande insulto em toda a América Latina, denotando a condição colonialista com que ainda era vista. Os periódicos reagiram fortemente às alegações do autor espanhol, em especial as revistas citadas anteriormente. Carpentier escreve respostas ao texto de Torre e aos editores que a publicaram, reafirmando, uma vez mais, seu posicionamento.

O complicado cenário político cubano e a constante ameaça de ser preso novamente fizeram com que, em 1928, Carpentier tirasse proveito de algumas circunstâncias e fugisse para a Europa. Em março desse ano o poeta surrealista francês Robert Desnos estava de passagem por Havana em razão de um congresso de jornalistas. Tomando conhecimento da situação, oferece seu passaporte a Alejo que, com a ajuda do poeta Mariano Brull, 
então funcionário da embaixada francesa em Cuba, facilitou seu embarque para território europeu. Essa segunda viagem ao continente europeu, já em época adulta, acarreta um período de intensa formação intelectual e artística.

\section{Europa: a configuração de um projeto}

Contrariando a proposta de Said, que afirmara que "ver um poeta no exílio - ao contrário de ler a poesia do exílio - é ver as antinomias do exílio encarnadas e suportadas com uma intensidade sem par" (SAID, 2003, pp.46-47), o que podia ser visto no cotidiano do autor cubano era uma intensa vivência cultural e diversas articulações profissionais. Quando instalado em Paris, nesse período Carpentier colabora com diversas revistas de vanguarda francesas e conhece promotores e representantes das novas estéticas de então, como André Breton, Pablo Picasso, Tristan Tzara, Ernest Hemmingway, Nicolás Guillén, Wifredo Lam, Pablo Neruda, Heitor Villa-Lobos, entre tantos outros. Participa ativamente de tertúlias literárias em Madri, onde se encontra com figuras como Rafael Alberti, Federico García Lorca e Miguel Hernández.

Além de colaborar com periódicos, escreve pequenas peças, como Yamba-Ó, uma tragédia burlesca que se encena em Paris e foi musicada por François Gaillard. Enquanto isso, seus textos inspiram artistas em Cuba. Ainda em 1928, estreia em Havana o balé La Rebambaramba, com música de Amadeo Roldán baseada em um livreto de Carpentier. No ano seguinte, continua escrevendo pequenos livros de gêneros variados, como autos, poemas, canções e óperas. Nesse ínterim é convidado pelo escritor André Breton a colaborar com a revista A Revolução Surrealista.

O período inicial em Paris foi marcado por um contato mais intenso com as propostas surrealistas. Apesar da constante colaboração em revistas sobre o tema e dos debates com alguns dos principais expoentes dessa vanguarda, em pouco tempo Carpentier diz ter se desvinculado de suas propostas básicas, passando a considerar o movimento como uma "literatura de receita". Entre os muitos textos que escreveu criticando o Surrealismo, o mais famoso pode ser considerado o que se converteu em Prólogo a El reino de este mundo, no qual lança suas ideias sobre o real maravilloso da América. Apesar de ter sido publicado anos depois, já em finais da década de 1940, as bases da ideia carpentieriana foram formuladas nos anos de 1930, no momento de sua dissidência da corrente bretoniana do surrealismo e a partir do contato com escritores latino-americanos que também se encontravam na Europa, como Miguel Ángel Asturias e Arturo Uslar Pietri. É o contato com todo esse contexto que faz com que Carpentier passe a buscar as senhas de identidade de sua América. O afastamento do Surrealismo, no entanto, não se dá da forma como Carpentier assumiu, como veremos em sessão posterior; sua produção aponta vínculos com o movimento mesmo depois da suposta rescisão.

Em 1985, Arturo Uslar Pietri rememora os momentos que passou em companhia de Carpentier e de Asturias. São suas palavras:

Desde 1929 y por algunos años tres jóvenes escritores hispanoamericanos se reunían, con cotidiana frecuencia, en alguna terraza de un café de Paris para hablar sin término de lo que más les importaba, que era la literatura de la hora y la situación política de la América Latina que, en el fondo, era una misma y sola cosa. Miguel Ángel Asturias venía de la 
Guatemala de Estrada Cabrera y Ubico, con la imaginación llena del Popol Vuh, Alejo Carpentier había salido de la Cuba de Machado y yo venía de la Venezuela de Gómez. En Asturias se manifestaba, de manera casi obsesiva, el mundo disuelto de la cultura maya, en una mezcla fabulosa en la que aparecían, como extrañas figuras de un drama de guiñol, los esbirros del Dictador, los contrastes inverosímiles de situaciones y concepciones y una visión casi sobrenatural de una realidad casi irreal. Carpentier sentía pasión por los elementos negros en la cultura cubana. Podía hablar por horas de los santeros, de los ñáñigos, de los ritos del vudú, de la mágica mentalidad del cubano medio en presencia de muchos pasados y herencias - Yo, por mi parte, venía de un país en el que no predominaban ni lo indígena, ni lo negro, sino la rica mezcla inclasificable de un mestizaje cultural contradictorio. La política venía a resultar un aspecto, acaso el más visible, de esas situaciones de peculiaridad que poco tenían que ver con los patrones europeos. ¿Qué podía haber en común entre el señor Poincaré y Estrada Cabrera, Machado y Gómez, y qué podría identificar al maestro de la Escuela de Guatemala convertido en tirano, al rumbero y trágico habanero tradicional que era Machado y al caudilo rural, astuto e instintivo que era Gómez? Lo que salía de todos aquellos relatos y evocaciones era la noción de una condición peculiar del mundo americano que no era posible reducir a ningún modelo europeo. (PIETRI, 1985, p. 01-02)

Os debates entre os escritores foram decisivos para a formulação das principais ideias de Carpentier, as quais foram, ao longo do tempo, aprimorando-se e atualizando-se. Nesse sentido, mais uma vez a experiência de Carpentier contraria as principais premissas da noção de exílio. É consensual entender que este opera uma cisão identitária, um afastamento não apenas geográfico, mas do imaginário de sua pátria e seus compatriotas. No entanto, o que se observa aqui é uma maior aproximação e entendimento das raízes, uma mais profunda consciência de identidade e uma maior vinculação ao imaginário do país natal. Em 1933, em Madri, publica sua primeira novela, Écue-Yamba-Ó. Renegada pelo autor anos depois, trata-se de um romance afro-cubano escrito durante o período que passou na prisão, que ainda hoje funciona como um marco na escritura negrista do continente.

De acordo com Selena Millares (2005), é durante o período em Paris que o autor se casa com uma suíça que morre de tuberculose e, pouco depois, com Eva Fréjaville, com quem romperá quando de seu regresso a Cuba e que teria inspirado a personagem Mouche, de Los pasos perdidos.

Ainda em 1933, a queda de Gerardo Machado e os ares revoltosos animaram Carpentier a emitir passaporte para voltar à ilha, o que, desta vez, reforça positivamente o senso comum sobre o exilado e a saudade da terra natal. No entanto, a instabilidade política, econômica e social que se seguiu o fez mudar de ideia. A Rebelião dos Sargentos e a tensão entre Grau San-Martín, Antonio Guiteras e Fulgencio Batista indicavam que era mais seguro manter-se distante. A comprovação do cenário instável veio em 1934, com o fechamento da universidade, a ilegalidade dos sindicatos e com a regra de prisão e tortura dos ativistas políticos (ver Gott, 2006). A revolta de 1933 instaura um cenário controverso, que limita a intervenção dos Estados Unidos através do golpe militar articulado por Fulgencio Batista, dando poder a Ramón Grau. Nesse ínterim, ocorrem avanços, como a suposta queda da Emenda Platt, direito das mulheres ao voto e redução da jornada de trabalho.

Em 1936, Carpentier faz uma rápida visita a Havana, levado pela nostalgia, e volta ainda surpreendido pelo mal-estar social, a corrupção e a repressão constantes na cidade. Apenas após a associação do Partido Comunista com Fulgencio Batista, dando a Cuba alguns anos com menor tensão social, é que Carpentier regressa à ilha. O retorno se dá 
em 1939, com o início da Segunda Guerra Mundial. Nesse contexto, considerando as motivações do regresso, poder-se-ia aventar um exílio, já que houve uma causa claramente associada à violência para que deixasse Paris.

\section{O regresso a Cuba: 1939-1945.}

O início de mais uma guerra de proporções continentais na Europa fez com que muitos daqueles que lá estavam exilados voltassem a seus países de origem. Foi o que fez Carpentier entre 1938 e 1939, unindo a saudade da terra natal às barbaridades feitas pelo nazismo as quais tinha que narrar no programa de rádio que apresentava à época na França. A situação geral de Cuba havia melhorado, a economia começava a estabilizar-se, vários intelectuais haviam regressado à ilha, sobretudo após a aliança de Batista com a esquerda política. Nesse momento, separa-se da esposa e volta para Cuba sozinho, onde se engaja com atividades da esfera artístico cultural, trabalhando em rádios e musicando peças para diversos fins. Continua colaborando com vários periódicos, como a Revista Cubana, La Gaceta del Caribe e a revista Orígenes.

Em 1941, em Santa María del Rosario, casa-se com Lilia Esteban Hierro, com quem seguirá casado até sua morte, em 1980. Nesse mesmo ano oferece um curso de História da Música no Conservatório Nacional de Música Hubert de Blanck, em Havana. No ano seguinte, organiza a primeira exposição de Picasso na capital cubana. É também durante esse período da vida que se debruça sobre a história da música em Cuba, tema sobre o qual lançará um livro que é considerado, hoje, o primeiro a tratar em detalhe sobre o assunto. Inicia vários trabalhos que não chega a terminar, como um romance sobre o Grupo Minorista, intitulado El clan disperso.

Em 1943 faz uma viagem que dará um rumo fundamental para sua escritura e para sua concepção da realidade americana. Em companhia de sua esposa e do autor francês Louis Jouvet, vai ao Haití. Ali se deslumbra com a cultura e o povo, mas também com a natureza e as construções. Impressiona-se com as ruínas da fortaleza do ditador negro Henri Christophe, construída com sangue de touro. Essa viagem provê a base a partir da qual pensará o romance El reino de este mundo, que só irá publicar em 1949. Em 1944 publica Viaje a la semilla, um breve romance que, segundo o autor, será um marco decisivo na sua escritura e modo criador.

Apesar da superação de diversos problemas, Cuba ainda se encontra dividida. O cenário cultural, mais especificamente, transita entre dois pólos, o primeiro é o dos já conhecidos Nicollás Guillén, que voltou para a ilha no mesmo ano do regresso de Carpentier, e Juan Marinello; ambos estavam concentrados no âmbito governista e do Partido Comunista. O segundo é do grupo da revista Orígenes, liderado por José Lezama Lima.

A revista Orígenes (1944-1956) foi também um marco importante na história literária de Cuba. De acordo com Echevarría e Pupo-Walker (2006), na publicação confluem a poética abstrata, o lirismo e a especulação filosófica. Sua principal proposta se baseava no debate sobre uma cultura nacional cubana fora do alcance estritamente político, fomentando a nacionalidade como uma construção metafísica, alheia à esfera política, ahistórica e atemporal. Apesar de ser esse o eixo comum da revista, nem todos os que nela publicavam se alinhavam a ele.

Carpentier colaborava com ambos os grupos e disse simpatizar com os postulados de ambos, que não julgava incompatíveis. Como será possível ver mais adiante, neste tra- 
balho, faz parte da poética carpentieriana considerar, ao mesmo tempo, a busca por uma cubanidade, ou melhor, uma americanidade, em paralelo à busca pelo universal. $\mathrm{O}$ modo de acessar essa identidade também revela um teor metafísico, muito embora em medidas bastante distintas das consideradas por Lezama.

\section{Venezuela. Os "passos redescobertos" (1945-1959)}

Apesar de seu regresso à Cuba se dever a uma possível estabilidade na ilha, é certo que em nenhum momento o cenário esteve de fato pacífico. Em 1945 Carpentier teve a oportunidade de tentar um novo destino o qual, talvez, libertasse-o da atmosfera ainda opressiva pela qual estava cercado. É atendendo ao pedido de um amigo, Carlos Frías, que vai trabalhar em Caracas, Venezuela, como produtor de anúncios de rádio e televisão numa agência de publicidade chamada Ars, dirigida por Frías. Antes disso recusou uma oferta para trabalhar em Nova York, para a Columbia Broadcast Company, também em programas de rádio, dessa vez com a temática "hispanoamérica", por julgar que era o momento de regressar à Cuba. Ocorre aqui um novo período de expatriação voluntária, por considerar que Cuba não reunia condições suficientes para trabalhar e produzir com o conforto e dignidade que julgava minimamente necessários.

Durante todo o período que permaneceu em Caracas, Carpentier esteve ligado à agência Ars. No entanto, como já era de seu perfil, não se limitou a esse único labor. Também dirigiu programas de rádio e passou a colaborar com o jornal El Nacional, entre 1946 e 1958.

Em 1946, é publicado, no México, seu livro La Música en Cuba, no qual reunia um conjunto de análises da história da música em Cuba associadas com os acontecimentos históricos, sociais e culturais do país. Nessa obra propõe que as origens musicais da música cubana estão no sincretismo de elementos cubanos e haitianos, evocando e reforçando a tendência negrista da ilha. No mesmo ano, é convidado a conduzir trabalhos na cátedra de história da cultura na Escuela de Artes Plásticas Cristóbal Rojas, função que exerce até 1957, e a dar aulas na Universidad Central.

Em 1947, mais uma viagem rearranja o rumo dos pensamentos do autor. Nesse ano, percorre um trajeto pelo país que o leva a conhecer a Gran Sabana venezuelana, o território amazônico e o Alto Orinoco. Esse deslocamento não só reafirmará o que formulara no Haiti, como lhe dará novos motes para outros romances, sobretudo para Los pasos perdidos, o qual será publicado em 1953. Carpentier considerava a Venezuela o país onde se concentravam, a uma só vez, todas as características da América Latina. Em suas palavras:

En Venezuela descubrí dos cosas. En primer lugar, un país muy bello, en el que encontraba más facilidades que en Cuba para escribir mis libros, y por otra parte, esta estancia en Venezuela me permitió conocer más a fondo a esta América que me apasionaba. Venezuela es quizá el único país de América del Sur que presenta toda clase de paisajes; es una especie de compendio telúrico de América. Algunos países de América no poseen grandes ríos; otros carecen de montañas o llanuras, mientras que en Venezuela encontramos la selva virgen, ese río inmenso que es el Orinoco, montañas como los Andes, una costa tropical, islas de perlas, una vegetación prodigiosa y la llanura inmensa, cuya travesía a caballo puede durar diez o doce días, de forma que constituye una especie de enciclopedia de la naturaleza americana con todos esos elementos, unos al lado de los otros. (CARPENTIER apud CHAO, 1998, pp. 147-148) 
Quando volta para Caracas, redige a primeira parte de Visión de América, coleção de cinco artigos que serão publicados integralmente mais adiante, em 1948, na revista Carteles. Termina El reino de este mundo em 1948. No mesmo ano publica o que seria o prólogo a esse livro em sua sessão de El Nacional, num texto intitulado Lo real maravilloso de América. A publicação, no entanto, não produz muitos comentários e passa despercebida até o lançamento do romance, em 1949. Em 1951, estreia uma nova coluna no jornal, intitulada Letra y solfa. Nessa sessão falava de literatura e música, como sugere o título, mas também de política e de sua visão da América Latina de uma forma geral e publicaria, até 1959, mais de três mil artigos. Segue colaborando com publicações em outros periódicos, inclusive em Cuba, onde publica através da revista Orígenes, em 1952, o conto Semejante a la noche.

Três anos mais tarde, em 1955, mais uma viagem lhe dá ideias para mais um romance. Dessa vez trata-se de uma ida a Paris que, por incidente do destino, faz uma escala para reparos na ilha de Guadalupe. É então que concebe El Siglo de las Luces, que só publicará depois. Em 1956 publica em Buenos Aires a novela El acoso. No mesmo ano, em Caracas, oferta um curso sobre literatura contemporânea e organiza o Segundo Festival de Música Latinoamericana. No mesmo ano, publica sua única obra teatral, La aprendiz de bruja. Também em 1956, recebe, em Paris, o prêmio de melhor autor estrangeiro por seu romance Los pasos perdidos.

Outra viagem, dessa vez às Antilhas Francesas, marca o ano de 1958, bem como a edição de Guerra del tiempo y otros relatos, obra na qual se incluem El acoso e mais três contos: El camino de Santiago, Viaje a la semilla e Semejante a la noche. De acordo com Selena Millares,

El extenso período venezolano de Alejo Carpentier, transterrado en un país hermano, supone la estabilidad siempre anhelada, tanto en el plano emocional y económico como en el creador. No obstante, la situación del país dista mucho de ser halagüeña: de hecho, al poco tiempo de su llegada a Caracas, en octubre de 1945, se produce un período de violencia y golpes de Estado, y en noviembre de 1948, otro que derroca al presidente Rómulo Gallegos, y las tiranías se suceden. La problemática no afecta tan sólo a Venezuela y Cuba: la Argentina de Perón, la Colombia de Rojas Pinilla o el Perú de Odría siguen los mismos rumbos. El pesimismo de las novelas de Carpentier, tan cuestionado, tenía buenas razones para manifestarse. (MILLARES, 2005, p. 27)

1959 foi o ano de grande revolução em Cuba. Foi também o ano em que Carpentier regressou à ilha.

\section{Cuba, uma vez mais (1959-1966).}

O triunfo da Revolução Cubana, em 1959, fez Carpentier retornar a Havana. Sua identificação com o novo ideal governamental era enorme e logo foi designado como administrador geral da Editorial de Libros Populares de Cuba y el Caribe. Passa a publicar mais intensamente em diversas revistas cubanas e termina a redação final de El Siglo de las Luces, que é publicado no México e na França em 1962. Em 1960, é nomeado vice-presidente do Conselho Nacional de Cultura pelo governo revolucionário. Também passa a ocupar o cargo de vice-presidência da união de escritores e artistas de Cuba. Em 1962 é 
nomeado diretor executivo da Editora Nacional, cargo que ocupa até 1966. Durante esse período também dá aulas sobre História da Cultura na Universidad de La Habana.

A atuação de Carpentier no novo governo cubano é intensa e comprometida. Apenas em 1963 consegue publicar mais de 16 milhões de livros. Organiza festivais culturais para a população cubana, sobretudo relacionados à música. Anos mais tarde, em uma entrevista, Carpentier se orgulha do trabalho editorial que empreendeu. Diria que "antes de la Revolución había once librerías em Cuba; hoy tenemos cuatrocientas veinte. Somos testigos de una enorme difusión y penetración de la cultura" (Carpentier apud Millares, 2005, p. 29).

No ano de 1964 publica uma coleção de ensaios intitulados Tientos y diferencias, que reúne importantes etapas do pensamento do autor as quais serão comentadas em outra sessão deste trabalho. A Revolução Cubana exerceu uma função importantíssima para a vida de Carpentier, a partir dela conseguiu ter espaço de realizar sonhos e pôr em prática várias de suas propostas a respeito da cultura na América Latina. Sobre a Revolução, comenta, em entrevista a Ramón Chao, na década de 1970:

No sólo yo, sino los hombres de mi generación, hemos encontrado en la Revolución la realización de lo que habían sido nuestras aspiraciones profundas. Los casos de abandono dignos de mención se cuentan con los dedos de una mano. Y yo no diría que esas aspiraciones eran solamente cubanas, sino también latinoamericanas en general. Es decir, que nuestra esperanza de una América diferente, de una América mejor, proyectada hacia el porvenir en un clima de justicia, de dinamismo, de fuerza y de afirmación de las diferentes nacionalidades encontró en la Revolución Cubana y en las palabras de Fidel Castro una concretización. [...] [la revolución] ha dado un sentido a mi quehacer. Hoy sé que puedo actuar en función de algo; que los anhelos, las indagaciones, las rebeldías que venían bullendo en mí desde los días de mi fraterna amistad con Rubén Martínez Villena - sin olvidar mis coloquios de cada tarde, no tantos años después, con César Vallejo - no habían madurado en vano. He cobrado conciencia, como nunca, de que la tarea de expresar ideas mediante la letra escrita o la letra hablada podía cumplirse en función de utilidad. Y eso lo debo a la Revolución Cubana. (CARPENTIER apud CHAO, 1998, p. 35-36)

É interessante perceber como, a partir de 1959, Cuba não representa mais, para Carpentier, um espaço de ameaça e desconforto. O cenário pós-revolucionário reuniu um conjunto suficientemente satisfatório de condições para ser habitada por ele. Embora tenha outros largos períodos longe da ilha, expatriação e exílio não mais formaram parte da experiência do autor com relação à sua terra natal.

As relações de apoio e engajamento entre Carpentier e o governo cubano se darão até o fim de sua vida, em 1980. Em 1965 realiza uma série de viagens pelo leste europeu que culminam, em 1967, na apresentação de denúncias de crimes realizados pelos Estados Unidos contra o Vietnam no Tribunal Russel em Estocolmo. Em 1966, volta à França como representante cubano, ocupando o cargo de ministro da embaixada de Cuba na França até o ano de sua morte.

\section{De volta a Paris}

Os últimos anos da vida de Carpentier transcorrem, predominantemente, em Paris. Em 1966, é nomeado embaixador de Cuba na França, e aí volta a residir até seus últimos dias. 
Realiza ocasionais viagens pela Europa e América, em exercício da função, mas é em Paris que fixa residência. Nesse período sua fama como escritor se alastrou pelos países europeus, em decorrência da tradução de sua obra a vários idiomas, como o inglês, russo e alemão. Em 1970 é nomeado membro da Associação de Compositores e Escritores da França. Em 1973, em Havana, é filmada uma série de quatro documentários sobre o autor, subdividida em Havana, seus romances, o Surrealismo e a música popular em Cuba.

No ano em que completou setenta anos, publicou dois romances importantes de sua carreira: El Recurso del Método e Concierto Barroco. Em 1975, recebe o título de Doutor Honoris Causa da Universidad de la Habana e volta a Caracas para realização de uma série de conferências, compiladas em Razón de Ser. Nesse mesmo ano, recebe homenagens no México e é eleito melhor autor estrangeiro na França, através do romance El Recurso del Método. Ainda em 1975 recebe o prêmio francês Cino del Duca, no valor de 38.000 mil dólares, destinado ao reconhecimento de autores cujo trabalho tenha se destacado no campo do humanismo. Doa o valor recebido, integralmente, ao Partido Comunista de Cuba. É cogitado diversas vezes ao prêmio Nobel.

Nesse período aceita o cargo de deputado do município de Havana Vieja na Assembleia Nacional, embora siga residindo predominantemente na França. Em 1977, ganha o que talvez seja o maior prêmio oficial de sua carreira de escritor. Trata-se do prêmio espanhol Miguel de Cervantes, a mais alta distinção literária do país. Carpentier é, inclusive, o primeiro intelectual latino-americano a recebê-lo. Mais uma vez, doa integralmente o valor recebido ao Partido Comunista.

Em 1978, publica La consagración de la primavera. No ano seguinte, já bastante debilitado por um câncer na laringe, contra o qual lutava havia já alguns anos, publica seu último livro, El arpa y la sombra, uma de suas principais obras. Morre em 1980, a 24 de abril, em Paris. Seu corpo foi transladado para Havana, onde recebeu homenagens de diversos setores da sociedade. Sua morte interrompeu vários projetos que tinha em andamento, como um romance sobre as heroínas da Revolução Cubana e um livro de memórias.

\section{Considerações finais: a viagem como realidade e como metáfora}

A noção de viagem e de exílio supõe um deslocamento de espaços entre um ponto e outro do mapa. Essa transposição impõe, necessariamente, uma dimensão temporal, já que é necessário tempo para vencer espaços e chegar ao destino. Voltando-nos para a literatura, percebemos registros de viagens memoráveis que transpunham largos espaços, mas que não necessariamente relatavam essa dimensão. Relatos de viagem, muitas vezes, contam não apenas o que se viu durante a perambulação, mas a percepção do que se era e do que se passou a ser depois da experiência.

É justamente a dimensão da experiência que é fundamental quando falamos de Carpentier. Ao relacionar seus escritos e sua biografia com viagens, não queremos apontar que o que fez foi, em sentido estrito, uma literatura de viagens ou de exílio. Na verdade, a viagem importa aqui na dimensão da experiência e da percepção que esta desperta. Retomando o que foi dito por Ianni no início deste trabalho, podemos entender tanto a vida como a obra de Carpentier como definidos pela viagem, como realidade e como metáfora. Realidade por sua materialidade, porque foi experiência concreta, metáfora porque foi também experiência de percepção, de maleabilidade temporal e expansão das fronteiras da própria percepção das coisas e do mundo. 
Essa expansão da percepção se manifestou, na produção carpentieriana, sobretudo na dimensão temporal e histórica do humano. Em suas viagens constatou que os tempos se sobrepunham não necessariamente de forma consecutiva, mas concêntrica, formando elipses sobre as quais se pode dar voltas através de transposições espaciais. É o que ocorre, por exemplo, na viagem que realizou pela selva venezuelana, em seu percurso pelo rio Orinoco.

De repente empecé a mirar el paisaje del Orinoco como una materialización del tiempo. Ese viaje hacia las fuentes (no llegué a ellas, desde luego) pero a contracorriente, era una recurrencia en el tiempo. Y, efectivamente, a medida que adelantaba a lo largo del río veía poblaciones que cada vez se iban alejando más en el tiempo, separándose de lo que podíamos llamar la historia actual y contemporánea. Iban desapareciendo los periódicos, la radio, las comunicaciones; la gente no sabía lo que pasaba en el mundo y se iba entrando en una vida que más o menos se parecía a la de la Edad Media en Europa.

Entrando ya en la zona amazónica, me di cuenta de que América es uno de los pocos lugares del mundo donde el hombre del siglo XX puede convivir con el hombre que corresponde a la era, diríamos, del Paleolítico o Neolítico en la historia humana. Allí puede el hombre de hoy dar la mano a un hombre no menos inteligente que él, porque la noción de salvaje es completamente falsa; puede convivir, digo, con el hombre que él mismo fue sobre la Tierra hace veinte, treinta o cuarenta mil años. (CARPENTIER apud CHAO, 1998, p. 151)

Esse processo de "volta no tempo" é ficcionalizado em Los pasos perdidos, romance com evidentes notas autobiográficas, quando o protagonista recria a experiência de Carpentier no sentido inverso da evolução humana, rumo ao que ele chama de Paleolítico ou Neolítico da história. A percepção das semelhanças e diferenças, através de uma mirada antropológica sobre o que era possível conhecer durante suas viagens se uniu a uma curiosidade eventualmente pitoresca e contemplativa, de admiração e deslumbramento, com relação às realidades que se lhes apresentavam pelos caminhos que cruzava. Nesse sentido, a viagem parece operar de duas formas diferentes, mas não totalmente dissociadas. A primeira delas é a viagem como exílio, por segurança, para salvaguardar-se dos perigos e ameaças que seus posicionamentos implicavam. As viagens para a Europa, sobretudo, ficaram marcadas por esses traços, ainda que não tenham se limitado a eles. $\mathrm{O}$ segundo tipo são as viagens de descobrimento, associadas ao insólito, ao inesperado, ao imprevisível. Apesar de todo o deslocamento ter servido, para Carpentier, humanista que era, como oportunidade de aprendizado, foram os descobrimentos, frutos do inusitado, que parecem ter transformado de forma mais profunda, clara e sistemática, seu modo de entender os assuntos que lhe eram caros e acabaram por condicionar suas teorias e opiniões sobre a América e, consequentemente, sua produção ensaística e narrativa.

Explico melhor. As viagens a Paris e à Espanha serviram como uma formação geral do intelectual Carpentier, do homem das Letras com formação clássica, poderíamos dizer. Nesse contexto, a aprendizagem parece ter sido muito mais enciclopédica, num sentido positivo do termo, que estrutural. Dava-se num âmbito conhecido, o da trajetória ocidental da história das ideias e do pensamento. O período de exílio de fins da década de vinte e década de trinta corresponde a essa aquisição e aprimoramento das bases da mentalidade eurocêntrica ocidental, que dava respaldo a toda a formação anterior do autor, a que lhe deram seus pais e as escolas onde estudou. Apesar das duas categorias serem distintas, possuem pontos de interseção. É impossível negar que a estadia na Europa durante o referido período foi fundamental para o surgimento da necessidade de repensar a América 
e suas idiossincrasias, de traçar contrapontos entre as diversas formas de conhecimento e organizações culturais da Europa e da América, em toda sua multiplicidade.

Às viagens de descobrimento correspondem outros trajetos, reais e metafóricos. A estes correspondem, por exemplo, as conversas nos cafés com Uslar Pietri e Asturias; ao compartilhar informações de seus países de nascimento, ocorria uma aprendizagem de outra ordem, estruturante dos saberes outrora obtidos, e remodeladora das formas ocidentais - de prestígio - de entender e organizar o conhecimento sobre as coisas do mundo, em especial sobre a América. Daí a importância dada a esses momentos de "charla", que constituíam verdadeiros trânsitos metafóricos de ideias e imagens, contextos e saberes, os quais foram importantes para a configuração dos projetos literários e biográficos dos autores. Também a essa denominação corresponderiam as pesquisas realizadas em arquivos e bibliotecas com textos e obras do passado americano, os quais também serviram como dínamo para as ideias de Carpentier.

Deslocamentos reais também serviram como viagens de descobrimento para Carpentier, desde as que realizou quando criança/adolescente até aquela que serviu de marco principal para a formulação concreta de suas ideias: a realizada em 1943 para o Haití. Essa viagem exerceu um papel fundamental para a produção carpentieriana e, sem ela, talvez nunca tivéssemos ouvido falar no real maravilloso de América. É ela que inaugura toda uma nova perspectiva para o projeto literário de Carpentier. A ela somam-se várias outras, também imprescindíveis para o desenvolvimento dos ideais do autor sobre o mundo - americano, europeu, sobre o homem universal. Entre elas merece destaque a que realizou na década de cinquenta pela Venezuela e que possibilitou a escrita de Los pasos perdidos, possivelmente sua obra de mais alto valor literário reconhecido.

Cada período de exílio, cada viagem, de segurança ou de descobrimento, reais ou metafóricas, empreendida por Carpentier parece deixar marcas em sua produção, inclusive as viagens que o antecederam, feitas por familiares seus. Da Suíça a Cuba, de Cuba a Rússia e Paris e de volta a Cuba e de lá novamente a Paris e Espanha. Novamente Cuba e então Venezuela, de volta a Cuba e depois Paris. De passagens foi a vida de Carpentier e de viagens se constitui sua literatura, ora como realidade, ora como metáfora. Os múltiplos espaços frequentados por Carpentier se conjugam no que ele escreveu e se projetam no que propôs, configurando o que Edward Said apontara e definira como uma "consciência de dimensões simultâneas", já que ele conseguiu "ver o mundo inteiro como terra estrangeira" (2003, p. 59), mas também achar múltiplos espaços para chamar de casa.

\section{Referências}

BOLAÑO, Roberto. El exilio y la literatura. Discurso en Viena de Roberto Bolaño. Revista Ateneo, $\mathrm{n}^{\circ}$ 15, p. 42-44, año 2001. Disponível em <http://www.memoriachilena. gob.cl/602/w3-article-73198.html> Acesso em 08.set.2019.

CARPENTIER, Alejo. Entrevistas. Alejo Carpentier. La Habana: Letras Cubanas, 1985. CHAO, Ramón. Conversaciones con Alejo Carpentier. Madrid: Alianza, 1998.

ECHEVARRÍA, Roberto González. Alejo Carpentier. The pilgrim at home. Austin: University of Texas Press, 1990.

ECHEVARRÍA, Roberto González. Carpentier, el extranjero (1904-1980). Disponível em $<$ http://www.letraslibres.com/revista/convivio/carpentier-el-extranjero-1904-1980> Acesso em 26/11/2014. 
ECHEVARRÍA, Roberto González; PUPO-WALKER, Enrique (eds). Historia de la Literatura Hispanoamericana vol. II. El siglo XX. Madri: Gredos, 2006.

GOTT, Richard. Cuba: uma nova história. Rio de Janeiro: Jorge Zahar, 2006.

IANNI, Octavio. A metáfora da viagem. In: Enigmas da Modernidade-Mundo. Rio de Janeiro: Civilização Brasileira, 2003.

MAGRIÑÁ, Maria Florencia. Exílio e literatura: fronteira, tradução e identidade.XXVII SIMPÓSIO NACIONAL DE HISTÓRIA. Conhecimento histórico e diálogo social.

Natal/RN, 2013. In: Anais dos Simpósios da ANPUH. Disponível em <https://anpuh. org.br/uploads/anais-simposios/pdf/2019-01/1548875177_768089d4f120f9d20b63f9e805007bla.pdf $>$ Acesso em 26/11/2014.

MILLARES, Selena. Alejo Carpentier. Madri: Editorial Síntesis, 2005.

MONTAÑÉS, Amanda Pérez. Vozes do exílio e suas manifestações nas narrativas de Julio Cortázar e Marta Traba. Florianópolis, 2006. TESE. Disponível em $<$ https://repositorio.ufsc.br/xmlui/bitstream/handle/123456789/89324/231627.pdf?sequence=1\&isAllowed=y>. Acesso em 08.set.2019.

MORENO, Amanda Brandão Araújo. Cartografia ensaística de Alejo Carpentier. 2018. Tese (Doutorado em Teoria da Literatura). Programa de Pós-Graduação em Letras da Universidade Federal de Pernambuco, Recife, 2018.

PIETRI, Arturo Uslar. Realismo mágico. 1985. Biblioteca Virtual Universal. Disponível em < http://www.biblioteca.org.ar/libros/131558.pdf> Acesso em 11/05/2016.

RIPOLL, Carlos. La Revista de Avance (1927-1930). Vocero de vanguardismo y pórtico de revolución. Revista Iberoamericana. Vol. XXX, Núm. 58, Julho-Dezembro, 1964. Disponível em < http://revista-iberoamericana.pitt.edu/ojs/index.php/Iberoamericana/ article/viewFile/2106/2300> Acesso em 09/05/2016.

RODRÍGUEZ, Alexis Márquez. Alejo Carpentier: teoría y práctica del barroco y lo real maravilloso. Caracas: Taurus, 2008.

ROLLEMBERG, Denise. Exílio: entre raízes e radares. Rio de Janeiro: Record, 1999. SAID, Edward. Reflexões sobre o exílio. In: Reflexões do exílio e outros ensaios. Trad. Pedro Maia Soares. São Paulo: Companhia das Letras, 2003.

Recebido em: 14/09/2019; Aceito em: 30/09/2019 